\title{
Evaluation of using dietary supplements among polish adult people below and over 60 years of age
}

\author{
Katarzyna Suliga', Teresa Grzelak', Joanna Grupińska ${ }^{1,2}$, Marta Pelczyńska', \\ Marcelina Sperling', Krystyna Czyżewska' \\ ${ }^{1}$ Division of Biology of Civilization-Related Diseases, Poznan University of Medical Sciences, Poland \\ ${ }^{2}$ Departament of General Chemistry, Poznan University of Medical Sciences, Poland
}

\begin{abstract}
Introduction. The population of elderly people is exposed to the development of disorders related to physiological ageing, as well as relatively common diseases occurring in the old age period. The gastrointestinal diseases, which reduce the absorption of many nutrients, are more frequent in the elderly compared to younger population.

Material and Methods. In the study was attempted the assess of conditions of dietary supplementation by 60 years old people or older (60+). The comparisons of results were obtained with relation to young adults and middle aged persons (18-58 years). The survey was conducted with 368 adult, including 123 respondents over 60 years old and 245 younger people.

Results. The study has been shown that dietary supplements were used by $64.2 \%$ of elderly people and $59.6 \%$ of younger respondents. The most common source of knowledge about dietary supplements in the elderly was a physician (40.7\%) in contrast to younger population, where dominated the Internet $(60.0 \%)$. The main reason of supplementation in the $60+$ group was an enhancement the immune system, while in younger population it was important to improve the appearance of skin, hair and nails. The most common components of supplements, which were used in the elderly population, were vitamin C (32.5\%) and magnesium (28.5\%) compared to younger group where the most popular were vitamin D (22.5\%) and magnesium (19.2\%).

Conclusions. The overuse of supplements, especially among the elderly, can lead to disability, therefore it is important to expand the education about side effects the improperly using of dietary supplements.
\end{abstract}

Keywords: dietary supplements, vitamins, minerals, senility.

\section{Introduction}

Older people belong to the population, which is especially exposed to the nutrients deficiencies. They are the result of decreased basal metabolic rate, which is a reason of reduced food intake while the request for macro- and micronutrients is constant. Frequent occurrence of diseases of the digestive system (including gastroesophageal reflux disease, chronic inflammation of the stomach, periodontitis, Helicobacter pylori infection, tumours or dyspepsia), as well as many drugs taken is also a problem. Deficiencies of vitamin $D$, calcium, and vitamin $B_{12}$ are particularly common in this population [1-4]. The increase of age- ing population, who despite the risk of malnutrition, is exposed on the development of immune response disorders leading to degenerative disease it has been observed. Dietary supplements intended for this part of population are becoming more popular $[3,5,6]$. These products are often used by patients in an uncontrolled way, without consultation with any specialist. The oral products, rich in nutrients, intended to complement a daily diet are called dietary supplements. They may contain vitamins, minerals, herbals, amino acids or other substances, such as enzymes, metabolites, probiotics, bee products [7]. According to the Act on the Safety of Food and Nutrition, "dietary supplements are 
foodstuffs, which purpose is to supplement the normal diet and which are concentrated sources of vitamins or minerals, or other substance with a nutritional or physiological effect [8]". In many cases the supplementation in the elderly is totally justified, especially when diet is not able to cover the requirements of the macro- and micronutrients. However, it does not mean that dietary supplements should be used without any restrictions. The supplementation of many nutrients should be justified by an unbalanced diet, healthy state, recent and current diseases, drugs taken or other factors, e.g. psychological or economic $[1,7]$. The purpose of the study was to evaluate the conditions of using dietary supplements by 60 years old and elder people and to compare the results with population of young adults and middle-aged respondents (between 18-58 years).

\section{Material and methods}

The studies were conducted among 368 Poles both gender between months: February-May 2015 and November-December of the same year. After the preliminary analysis of obtained data, all respondents were divided into two groups. The first population consisting 60 years old and elder people (EP) counted 123 respondents. The second group included 245 adult respondents aged $18-58$ (GP). The average age in the EP was $67.3 \pm 5.4$ years, whereas in the GP $28.8 \pm 9$ years. The Body Mass Index (BMI) was used to evaluate the body weight. The mean $\left( \pm S D\right.$ ) value of BMl was $26.4 \pm 3.7 \mathrm{~kg} / \mathrm{m}^{2}$ in the EP and $22.9 \pm 4.3 \mathrm{~kg} / \mathrm{m}^{2}$ in the GP. Women predominated in both populations, respectively $68.3 \%$ of people in the elderly and $90.2 \%$ of younger respondents. The information needed to complete the study was obtained by using an anonymous questionnaire, which was available to fill in senior clubs, universities of the third age, and by the medical clinic patients. The questionnaire mostly contained single-choice questions. It was also a few multiple-choice questions and one question describing accepted dietary supplementation. Further issues concerned the details associated with intake of dietary supplements (e.g. type, frequency of using, causes of supplementation, place of purchase). In the survey were questions about gender, age, weight and growth of the body, education, place of residents, health status, and socioeconomic situation. The obtained results were statistically calculated using PQStat (Poznan, Poland) and GraphPad Prism 6 (San Diego, U.S.A.). Normality of the distribution of data was checked using Shapiro-Wilk test and homogeneity of variance was tested using Levene's test. There was not the normal distribution, therefore in the current analyses of statistical differences were used non-parametric tests (Mann-Whitney test, chi-squared test and Fisher test). Statistically significant level of error was established at $p<0.05$.

\section{Results}

The most of respondents came from the cities above $100,000(47.1 \%$ of the EP and $51.8 \%$ of the GP) and the other extent from small towns and villages. Older people usually had a secondary education (44.7\%), while among the people from population below sixty years old, dominated higher education (56.7\%). Statistically significant difference was found in the level of education between the EP and GP $(p<0.000001)$. Health and financial situation of the elderly respondents were worse than in younger population $(p=0.001)$.

Among people of the EP $64.2 \%$ and $59.6 \%$ of the GP, declared using dietary supplements regularly or occasionally. Statistically significant differences were not observed between groups in this aspect $(p=0.428)$. The percentage of frequency distribution of using dietary supplements among women and men was shown in the Table 1. Vitamin preparations were the most common type of dietary supplements in both populations ( $78.5 \%$ of the EP and $74.7 \%$ of the GP, no significant difference). Minerals were consumed less often, however the elderly people $(67.1 \%)$ chose them more frequently, than the population under sixty years old $(48.6 \%$, $p=0.0079)$. The intake of other supplements was at the similar level (32.9\% and $39.7 \%)$. Significant differ-

Table 1. The percentage of people both gender using (or not) dietary supplements in EP and GP groups

\begin{tabular}{lcccc}
\hline \multirow{2}{*}{ Groups } & \multicolumn{2}{c}{ People $60+(60-89$ years $)$} & \multicolumn{2}{c}{ People aged 18-58 } \\
\cline { 2 - 5 } & Men $(n=39)$ & Women $(n=84)$ & Men $(n=24)$ & Women $(n=221)$ \\
\hline The use of dietary supplements by respondents - regularly & $25.6 \%$ & $33.3 \%$ & $20.8 \%$ & $33.5 \%$ \\
\hline The use of dietary supplements by respondents - occasionally & $28.2 \%$ & $35.7 \%$ & $33.3 \%$ & $26.7 \%$ \\
\hline Not using dietary supplements & $46.2 \%$ & $31.0 \%$ & $45.9 \%$ & $39.8 \%$ \\
\hline
\end{tabular}

EP - group 60+; GR - adult persons aged 18-58; $n$ - number of persons 
ences were not obtained in the EP and GP between the dietary supplements consumption and state of health, drugs taken, excess body weight (according BMI) and also economic situation. In younger group of people with higher education than others $(p=0.007)$ and living in the big cities $(p=0.015)$ compared to the residents of small town and villages more often reached for dietary supplements (lack of discussed dependence in the elderly population).

In the $60+$ population the supplementation was mostly practiced 1-2 times per week (39.2\%) and every third person (32.9\%) declared daily intake discussed products. In the GP, dietary supplements were generally consumed each day (49.3\%). Between studied groups were not statistically significant differences for the above information. Funds allocated for preparations were below twenty zlotys per month in both populations. The most popular form of dietary supplements was tablets, usually purchased in pharmacies, both by the elderly and younger people. Water was a liquid used to sipping the supplements (respectively $92.4 \%$ of the EP and $95.2 \%$ of the GP).

Among people aged 60 and older $55.7 \%$ and $41.1 \%$ of the younger group declared a slight health improvement after using dietary supplements (statistically significant difference $p=0.036)$, while the EP $(11.4 \%)$ compared to the GP (34.9\%) less often noticed the significant benefits in general health $(p=0.00013)$. Elderly people more often (43.9\%) than representatives of second population (29.0\%) ascertained that the dietary supplements are rather beneficial in the health. The doctor turned out to be the most common source of information about dietary supplements $(p=0.018)$ among the elderly $(40.6 \%)$ compared with younger (19.6\%). In the EP $(22.8 \%)$ significantly less often $(p=0.0001)$ than in the GP $(60.0 \%)$ indicated that a knowledge is obtained from the Internet. In the elderly population dietary supplements were used more often, if the knowledge about products was confirmed by the doctor ( $p=0.00066$ ), but in the GP if it was obtained from the Internet $(p=0.00036)$. The study has also shown that older people more frequently $(p=0.010)$ than younger took dietary supplements because of the doctor recommendation. The reasons of using dietary supplements by respondents were presented in the figure (Figure 1).

Conducted research allowed to assess the most popular vitamins and minerals in the various groups. In both populations were usually used many supplementary preparations at the same time. In the $60+$ group the most common was vitamin $\mathrm{C}$ and in the younger group - vitamin D. In both populations the first choice mineral was magnesium. The elderly people more frequently consumed vitamin $C(p=0.0008)$ and magnesium $(p=0.047)$ and less often chose folic acid $(p=0.01)$ compared to younger. Significantly differences in the frequency of taking other B vitamins, calcium, iodine, iron, zinc, and omega-3 fatty acids were not observed. The percentage of using vitamins and minerals supplements was shown in the figure (Figure 2).

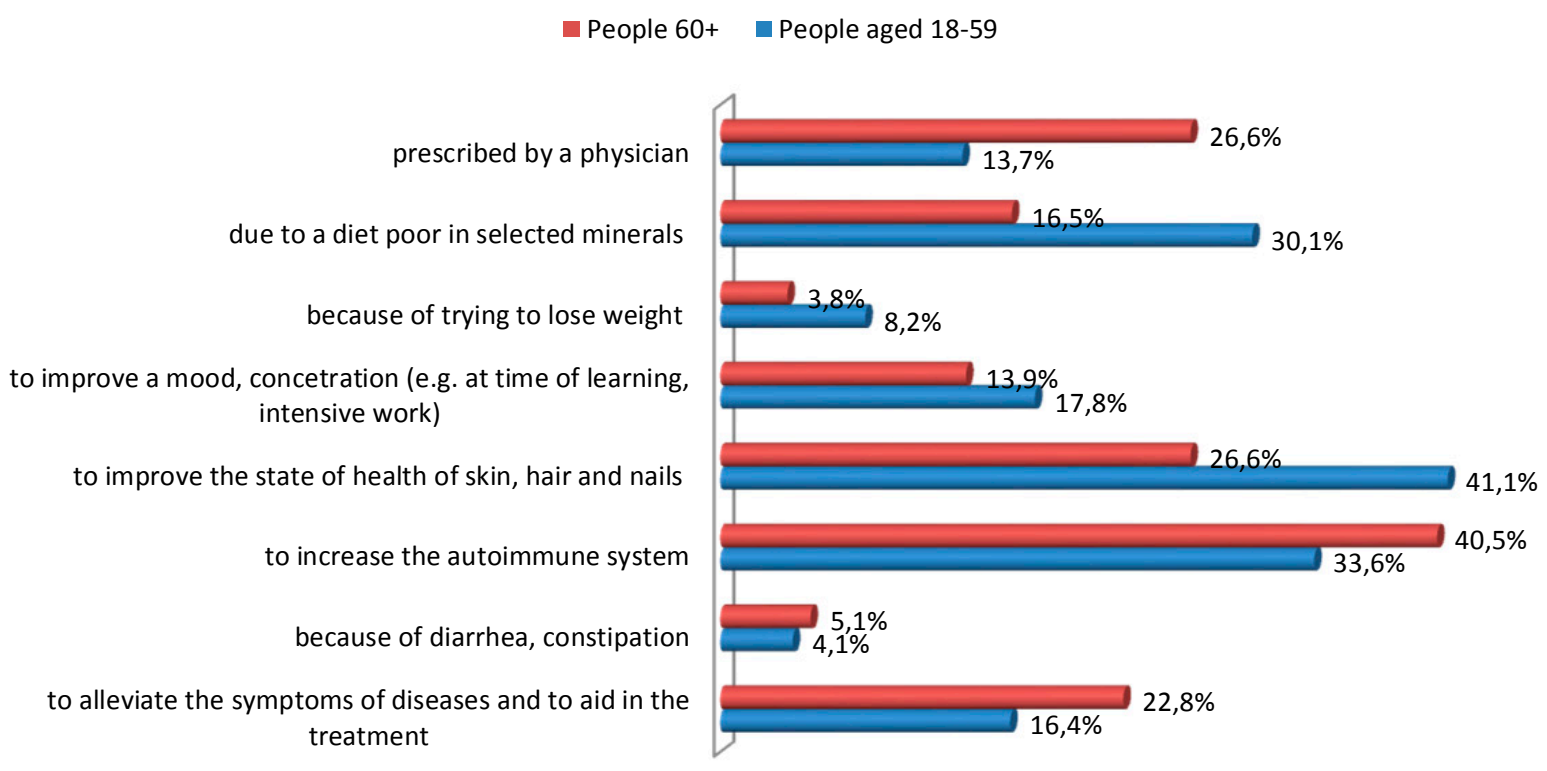

Figure 1. The reasons of using dietary supplements by respondents 


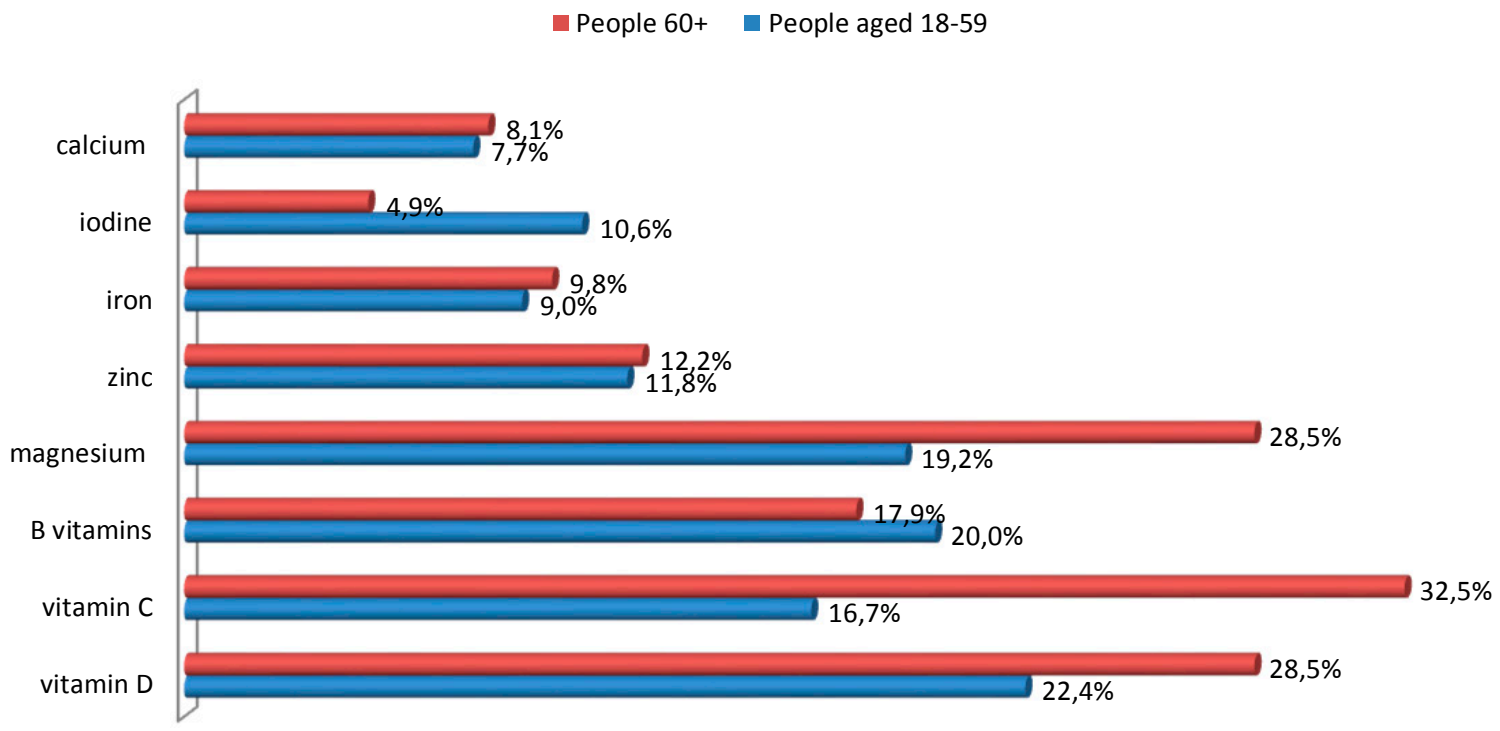

Figure 2. The percentage of people using vitamins and minerals

\section{Discussion}

Increasing number of people over 60 years old has been observed in Poland and other developed countries. Drop in birth rates and longer life expectancy of society were the main reasons for this phenomenon. The ageing process is associated with numerous physiological and biochemical changes, leading to difficulties in health maintenance. This is a period, while the border between physiological and pathological processes often becomes invisible. The structural and functional changes following in the ageing organism increase the vulnerability to various diseases. This is particularly visible in a digestive system, which improper functioning, affects to other systems of the body $[5,9]$. The adherence to a balanced diet, covering the demand for all nutrients, including vitamins, minerals and trace elements, as well as reducing the risk of diseases is very important in this period of life. Scientific studies indicate that the elderly people do not always follow to nutritional recommendations $[5,10]$.

Between the years 1994 to 1996 in the United States, Sebastian et al. reported that $42 \%$ of people aged $51-70$ and $43 \%$ of respondents over 70 years old consumed dietary supplements [11]. Similar results were obtained in a study conducted in 1999 among 206 75-80 years old people by Kaluza et al. This research determined that dietary supplements were used by $42 \%$ of people [6]. In the last 10-20 years this proportion increased by nearly 20 percentage points. The studies conducted by Saran and Duda between the years
2005 to 2006 , concerning using dietary supplements among older adults, have shown that consumption of these preparations declare $64.8 \%$ of respondents. In these analyses the similar percentage of population $60+(64.2 \%)$ assured of the dietary supplements intake (more or less regularly) [2]

Studies conducted by Saran and Duda indicated the relationship between using supplementation and the level of education in the group of elderly people. Dietary preparations were more often used by respondents with higher education than the other [2]. In population 60+ over discussed correlation did not occur in these analyses. Only in the group below 59 years old the highest percentage of representatives using dietary supplementation (independently of age) constituted the people with at least secondary education. During the similar research, conducted in 2006 by He et al. among people over 45 years old, indicated no relationship between the education and using dietary supplements. However, with increasing economic status, the frequency of this preparations intake also upswing [12].

As like in the current study, Saran and Duda has not determined a significantly relationship between using the dietary supplements and financial situation or health in the group of surveyed people [2]. Conducted analyses did not confirm the relationship between dietary supplements intake and place of residence, whereas Kaluza et al. and He et al. determined that city inhabitants more often than rural residents absorbed these preparations [6, 12]. The differences 
between presented study and analyses other authors may resulted from more interest dietary supplements, accessibility and universality an advertisements of the dietary supplements, also addressed to the consumers from little town and villages.

The discussed study showed that the most common cause of dietary supplements intake in the group of elderly people was a need to boost the immune system. Valid reason for taking supplements was also recommendation delivered by a doctor. A need to improve health was also a main reason for the implementation of supplements by the elderly people in a research executed by Saran and Duda [2]. It is worth noting that in the analyses respondents could choose one of many answers to define causes of dietary supplementation (Figure 1), which in most cases were associated with the general health improvement, also considering the need to improve the health condition of skin, hair, and nails (the main reason of supplementation in younger group of respondents). At the same time, it was found that after using dietary supplements, health in the elderly people was insignificantly improved, while the substantial benefits were observed in the second group. The coexistence of many diseases and polypharmacy in the elderly population, as opposed to younger may be a cause of this phenomenon [6].

Vitamin mostly consumed as a dietary supplement was ascorbic acid, as evidenced own study and analysis conducted in the US by Sebastian et al. The American team of researchers determined that vitamin $C$ was used by $33 \%$ of respondents between $51-70$ years old and by $30 \%$ of those over 70 years old [10]. In the analyses conducted by Kaluza et al. ascorbic acid was used by $38 \%$ of women and $20 \%$ of men. Considering the fact, that the intake of vitamin $\mathrm{C}$ in the diet does not cover the demand for this nutrient, ascorbic acid supplementation in the elderly can be justified [6]. Vitamin $\mathrm{C}$ is an important antioxidant, reducing the risk of cardiovascular diseases, which are a frequent cause of death, especially in the elderly. Moreover, due to a dental problems occurring in this population, consuming the main sources of vitamin $C$ (mainly raw fruits and vegetables) is significantly reduced $[6,13]$.

The presented analyses, as well as the work of Kaluza et al. showed a similar percentage of the older people supplementing with magnesium, although the average consumption of this macronutrient with a diet in the elderly was at a sufficient level [6]. Comparable results received Markiewicz et al. who analysed the magnesium intake with food in the elderly people living the Social Care Home in Bialystok, both in the summer how winter. Magnesium is an important component of diet in a prevention and treatment of hypertension and also in reduction the risk of coronary heart disease. Magnesium deficiencies predispose to development of type 2 diabetes and postmenopausal osteoporosis in women, due to the impact on calcium homeostasis [10]. Daily intake of magnesium with diet in the elderly population is usually at the adequate level, so the potential introduction of supplementation should be consulted with specialist, in order to avoid side effects of hypermagnesaemia, especially in patients with renal failure.

The particular attention was given to supplementation of vitamin $D$, because most of the data in over discussed study were obtained in months with a low sun exposure in Poland. Cholecalciferol deficiencies, resulting from reduced synthesis in older adults, are very widespread among the Polish population. Low blood levels of vitamin D may affect $80 \%$ of the elderly, especially living in the nursing homes. In presented analyses only about $30 \%$ of older adults declared consuming of this vitamin. It is worth noting that this was a bigger percentage of respondents than in the younger population. The former works showed a disturbing fact of the insufficient knowledge and awareness of people over 60 years old, associated with a necessity of cholecalciferol supplementation during periods, in which endogens synthesis in the cells of skin is quite reduced. A number of scientific reports indicate that the deficit of vitamin $D$ in the elderly people, increase the risk of developing osteoporosis, bone fractures, falls, muscle weakness, cardiovascular diseases, cognitive disorders, and cancers [14, 15].

The popularity of calcium supplementation in presented study in both groups turned out to be very low. According to the studies of various authors examining the intake of this component from food, the elderly people are often exposed on calcium deficiency. The causes of this phenomenon are low dairy products intake (mainly because of lactose intolerance), reducing the vitamin $D$ synthesis in the skin cells or decreasing the calcium binding proteins and protein transport. The studies of Markiewicz et al. and Kaluza et al. confirmed the fact that calcium is a macronutrient, which supplementation in the elderly seems to be justified or even indicated, but only in population without contraindications (e.g. without diagnosed nephrolithiasis). Tufts University's USDA Human Nutrition Research Center on Aging suggested a need of calcium and vitamin $D$ supplementation as part of the basic nutritional recommendations in the elderly $[1,6,10,14]$. 
Presented research provided alarming results regarding folic acid supplementation in the elderly. The study conducted by Stawarska et al., evaluating the individual vitamins and minerals intake by elderly people, determined a significant shortage of folic acid. Deficits of folate are very common in the elderly, and also dangerous due to the potential development of cardiovascular diseases, cancers, megaloblastic anaemia, rheumatoid arthritis and because of the predisposition toward development of dementia and deepening depression. Supplementation of folic acid should be used in older adults with confirmed deficiencies of folate, simultaneously with vitamin $B_{12}$ (wherein the absorption is reduced in the elderly). Presented study demonstrated a small percentage of people supplementing $B$ vitamins, including cobala$\min$. The long-term deficits of vitamin $B_{12}$ in the elderly contribute to the development of hematopoietic disorders manifesting by macrocytic anaemia, increase of homocysteine levels, and neurological symptoms e.g. peripheral neuropathy, demyelination of the white matter of the brain, paresthesias, lethary and apathy. The inadequate blood level of vitamin $B_{12}$ in older adults should be eliminated through the oral supplementation [1, 9, 16-18].

The current study reported that the iron and zinc supplementation is rare. The analyses carried out by Madej et al. among 102 people over 65 years old showed that traditional diet covered the demand for iron of almost all studied people. A different result was obtained in the case of zinc, which turned out to be insufficiency micronutrient in the elderly. This element is important in maintaining the integrity of a number of homeostatic mechanisms, including the immune function. Zinc is also the component allowing sense of taste and smell, proper functioning of the thyroid gland and pancreas, blood clotting, wound healing, cognitive function or appropriate function of the heart. Inasmuch as many studies confirm that older adults are exposed to zinc deficiency, therefore the use of dietary supplements containing this micronutrient in the elderly should be considered $[5,19]$.

The conducted analyses indicate that every fifth person over 60 years old consume polyunsaturated fatty acids omega- $3(n-3)$ as a supplement. Jablonowska et al. confirmed the low intake of these nutrients by the Polish population. Docosahexaenoic acid (DHA) and eicosapentaenoic acid (EPA) supplementation is particularly important for people, who in daily diet rarely include foods rich in over discussed components (e.g. marine fish, fish products, margarine). Before prescrib- ing supplementation should be encourage to frequent consumption of food containing natural forms of these acids. The numerous scientific reports indicated that $\mathrm{n}-3$ fatty acids minimalize the risk of coronary heart disease, type 2 diabetes, cancers, depression and inflammation. In the study conducted in the US by Farzaneh-Far et al. suggested that the omega- 3 fatty acids contribute to slowing down the aging process (by influencing the length of telomeres) $[20,21]$.

\section{Conclusion}

1) Vitamins and minerals as dietary supplements were common used by elderly people, regardless of education, place of residence, health and financial situation with a minor influence on health benefits. This phenomenon may be a result of co-existence of many diseases in the elderly population, compared to younger, in which the effect of supplementation were more visible.

2) Decisions about supplements intake by the elderly untaken with a physician may protect against health effects caused the abuse of these preparations. Health security is difficult to ensure in young adults and middle-aged people, suggesting the unverified data from the Internet.

3) The low intake of vitamin D, which deficiencies in the elderly are common, as well as the overuse of some dietary supplements without medical consultation, may be a reason of the high risk of hypo- or hypervitaminosis. There is a need to expand education among the elderly in the field of nutritional deficiencies, products rich in over discussed nutrients and potential dietary supplementation.

\section{Acknowledgements}

Conflict of interest statement

The authors declare no conflict of interest.

\section{Funding sources}

This research was supported by grants from Poznan University of Medical Sciences (Grant No. 502-01-2228371-04458).

\section{References}

1. Szcześniak P, Szukiewicz J, Michalak Ł, Orszulak-Michalak D. Żywienie i suplementacja diety wieku podeszłym. Farm Pol. 2009;65(11):775-779.

2. Saran A, Duda G. Wpływ wybranych czynników na zakup i stosowanie przez osoby starsze witaminowo-mineralnych suplementów diety. ŻYWNOŚĆ. Nauka Technologia Jakość. 2009;4(65):271-277.

3. Von Arnim CA, Dismar S, Ott-Renzer CS, Noeth $\mathrm{N}$, Ludolph AC, Biesalski HK. Micronutrients supplemen- 
tation and nutritional status in cognitively impaired elderly persons: a two-month open label pilot study. Nutr J. 2013 Nov;12(1):148. DOI: 10.1186/1475-2891-12-148.

4. Włodarek D. Suplementacja diety - wybrane zagadnienia istotne $\mathrm{w}$ praktyce lekarza rodzinnego. Nowa Klinika. 2012;19(5):5047-5050.

5. Mocchegiani E, Romeo J, Malavolta M, Costarelli L, Giacconi R, Diaz LE et al. Zinc: dietary intake and impact of supplementation on immune function in elderly. Age. 2013;35(5):839-860.

6. Kałuża J, Bagan A, Brzozowska A. Ocena udziału witamin i składników mineralnych z suplementów w diecie osób starszych. Rocz Państw Zakł Hig. 2004;55(1):51-61.

7. Glisson JK, Walker LA. How physician should evaluate dietary supplements. Am J Med. 2010;123(7):577-582.

8. [Internet] Ustawa o bezpieczeństwie żywności i żywienia z dnia 25 sierpnia 2006 roku (Dz. U. 2006 r. Nr 171, poz. 1225 z późn. Zm.). Available at: http://gis.gov.pl/zywnosc/suplementy-diety-zywnosc-wzbogacana-i-specjalnego-przeznaczenia/wymagania-szczegolowe/71-suplementow-diety (Accessed: 30.06.2017).

9. Duda G, Saran A. Polskie rekomendacje dotyczące spożycia witamin i składników mineralnych przez osoby w starszym wieku. Farm Współ. 2008;1:16-23.

10. Markiewicz R, Borawska MH, Socha K, Gutowska A. Wapń i magnez w dietach osób starszych z regionu Podlasia. Bromat Chem Toksykol. 2009;42(3):629-635.

11. Sebastian R, Cleveland L, Goldman J, Moshfegh AJ. Older adults who use vitamin/mineral supplements differ from nonusers in nutrient intake adequacy and dietary attitudes. J Am Diet Assoc. 2007;107(8):1322-1332.

12. He YN, Yang Z, Xu J, Sha YM, Ren ZY, Pang XH et al. Analysis on influence factor of dietary supplement used in population aged above 45 years in Beijng. Chin $\mathrm{J}$ Prev Med. 2008;42(11):823-826.

13. Otero-Losada M, Vila S, Azzato F, Milei J. Antioxidants supplementation in elderly cardiovascular patients. Oxid Med Cell Longev. 2013. DOI: 10.1155/2013/408260.

14. Kupisz-Urbańska M, Galus K. Epidemiologia niedoboru witaminy $D$ u osób w podeszłym wieku - wybrane zagadnienia. Gerontol Pol. 2011;19(1):1-16.

15. Bischoff-Ferrari HA, Shao A, Dawson-Hughes J, Hathcock J, Giovannucci E, Willett WC. Benefit-risk assessment of vitamin D supplementation. Osteoporos Int. 2010;21(7):1121-1132.
16. Stawarska A, Tokarz A, Kolczewska M. Ocena ilościowa składników mineralnych i witamin w dietach ludzi starszych zrzeszonych w wybranych warszawskich stowarzyszeniach społecznych. Bromat Chem Toksykol. 2009;43(2):117-122.

17. Brzozowska A, Sicińska E, Roszkowski W. Rola folianów w żywieniu osób starszych. Rocz Państw Zakł Hig. 2004;55(2):159-164.

18. Zabrocka J, Wojszel ZB. Niedobór witaminy B12 w wieku podeszłym - przyczyny, następstwa, podejście terapeutyczne. Geriatria. 2013;7:24-32.

19. Madej D, Borowska K, Bylinowska J. Dietary intakes of iron and zinc assessed in selected group of the elderly: are they adequate? Rocz Państw Zakł Hig. 2013;64(2):97104.

20. Jabłonowska B, Dłużniewska B, Jarosz A, Nowicka G. Ocena spożycia wielonienasyconych kwasów tłuszczowych n-3 wśród zdrowych dorosłych osób w odniesieniu do aktualnych norm żywienia. Rocz Państw Zakł Hig. 2011;62(4):389-396.

21. Farzaneh-Far R, Lin J, Epel ES, Harris WS, Blackburn EH, Whooley MA. Association of marine omega-3 fatty acid levels with telomeric aging in patients with coronary heart disease. JAMA. 2010;303(3):250-257.

Acceptance for editing: 2017-08-15 Acceptance for publication: 2017-09-30

Correspondence address: Division of Biology of Civilization-Linked Diseases, Department of Chemistry and Clinical Biochemistry Poznan University of Medical Sciences 6 Swiecickiego Street, 60-781 Poznan, Poland phone: +48618546476 fax: +48 618546476 email: katarzynasuliga@poczta.onet.pl 